\title{
Development of Chemistry Worksheet Based Learning Inquiry for Student in Senior High School
}

\author{
Sugiarti \\ Faculty of Mathematics and Science \\ Universitas Negeri Makassar \\ Makassar, South Sulawesi, Indonesia \\ sugiarti@unm.ac.id
}

\author{
Jusniar \\ Faculty of Mathematics and Science \\ Universitas Negeri Makassar \\ Makassar, South Sulawesi, Indonesia
}

\author{
Lukmanul Hakim \\ Universitas Negeri Makassar \\ Makassar, South Sulawesi, Indonesia
}

\begin{abstract}
The aim of this research is developing a model of student worksheet based learning inquiry on reaction rate that valid, practical and effective. This research is Research and Development model which refers to a 4-D development model consists of four phase, i.e.: (1) define a review set and the terms of learning starting with analysis aims of material restrictions to develop the devices, (2) design the aims that needed to prepare a learning tool prototype, (3) develop aims to review and produce learning tool that is valid, effective and practical, and (4) dissemination; in this stage is the usage of device has been developed more in a wide scale. The research subject was science-2 Student Class XI Senior High School-2 Polewali. Research results showed that (1) Student worksheet is valid based on the findings of the validation and limited testing process as well as revisions, (2) Effective, based on (a) the findings that students results meet the class completeness criteria, (b) activities Students in psychomotor and affective aspects results in very high and high category, respectively, (3) Practical responses by students and teachers against student worksheet on both categories showed good and very good category.
\end{abstract}

Keywords: student worksheet, guided inquiry, rate of reaction

\section{INTRODUCTION}

Instructional learning needs to develop interests of learners as well as a diverse but unified environment and remain responsive [1]. For that required instructional media such as student worksheets and learning model inquiry guided to improve the capacity and independence of the students through the steps, namely: (1) formulating the problem; (2) proposed a hypothesis; (3) collecting data through observation; (4) analyze and present data analysis results; and (5) to summarize and communicate [2].

Guided Inquiry is an activity where the problems raised by teachers or sourced from a textbook then students work to find an answer to the problem under the intensive guidance of a teacher. This type of inquiry learning is suitable to be applied in learning the concepts and principles underlying the particular field of science [2].

Based on observations and interviews obtained from teachers showed that the students' ability to understand the lessons constructs in chemistry learning still tends to be low because chemistry is considered difficult and takes thinking that high, but because of the concepts, as well as the calculations that require proficiency in the finish line with the concept that applies. Besides, they only use the ready-made worksheets from the publisher and the only source of learning that students use. It is considered one of the causes of student learning outcomes in subjects particularly chemistry material reaction rate is very low (49\%) were still far from the minimum completeness criteria $(80 \%)$ expected.

Matter of chemistry reaction rates as one of the subject matter of chemistry in grade XI that emphasize the concepts that some sub to its subject matter using a simple test that based on the syllabus of the curriculum. Based on the description above, the writer was interested in developing student worksheet in the subject "chemical reaction rates" based indicated inquiry valid, practical and effective in high school.

\section{RESEARCH METHOD}

This research is Research and Development model. The research subject conducted at Class XI Science-2. The procedure of this research adapted the research model of development of the 4-D developed by Thiagarajan, which consists of four main stages, namely: (1) definition phase; (2) the planning stage; (3) the development stage; and (4) the stage of dissemination/spread [3].

The research instrument was used validation worksheets, student activity observation sheet and achievement test to support the effectiveness of learning activities, as well as observation sheets has done and legibility Student Activity Sheet-based guided inquiry, while technical analysis of the data analyzed was qualitative descriptive. The worksheet was used to review its the validity in three scale categories, namely; very valid, valid, less valid and invalid.

\section{RESULTS AND DISCUSSION}

\section{A Phase I Defining}

Curriculum and student worksheet which is still conventional and the other hand students' interest in reading and understanding the language is high while academic ability to study is less because of laziness. Making it suitable for use student worksheets based inquiry guided. Ability responds to 
the task, and the concept of reaction rate on a worksheet students both in the classroom and in the laboratory is very good.

\section{$B$ Phase II Design}

In this phase, the media selection is based on material characteristics and students who refers to the learning objectives. The format student worksheets were developed according to the needs of students with the following: (1) the identity of worksheets that include titles, subjects, semester, and place; (2) instructions to learn; (3) the competence or the learning objectives to be achieved; (4) indicators; (5) supporting information; (6) tasks; (7) working steps; and (8) ratings.

The last is the preliminary design of Learning Implementation Plan (RPP), and the learning process is carried out as much as six meetings including achievement test. Whereas, student worksheet was designed to implement the learning strategy.

\section{Phase III Development}

(a) Expert assessment; (b) Suggestions from assessment experts there are errors in the writing, layout drawings or layout and the questions in the worksheet need to be improved and should be created a column information gathered. Revisions the instructional planning after going through expert validation, modification or revision are as follows: a) The code numbering for each item, b) the table format learning steps repaired, c) the activities of teachers and students in the learning steps shown, d) syntax guided inquiry learning model in learning steps detailed and clarified, e) use of worksheets displayed in learning steps, and f) assessment of cognitive added. These results indicate that the Student Worksheet in "very valid" category, with the average 3.32 validity.

\section{$D$ Development test}

The quantitative analysis of responses against student worksheet teachers at $100 \%$, indicating that the teachers give a positive response or "very good" category. The response of students to practicality student worksheet actively in learning and searching for materials and solve problems on worksheets, can motivate students because they want to know.

The test results directly student worksheet use in the classroom and the laboratory to students (limited test), the result of an average of $60 \%$ said good, the implementation by $95 \%$ and legibility test results by $82 \%$.

\section{1) The results of the benchmark test}

The results of the benchmark test include cognitive (81.25\%, higher category), The results of benchmark tests for effective (91\%, very high category) and psychomotor $(81.25 \%$, higher category, that indicates students enjoy on learning reaction rate using worksheets in the classroom and the laboratory.

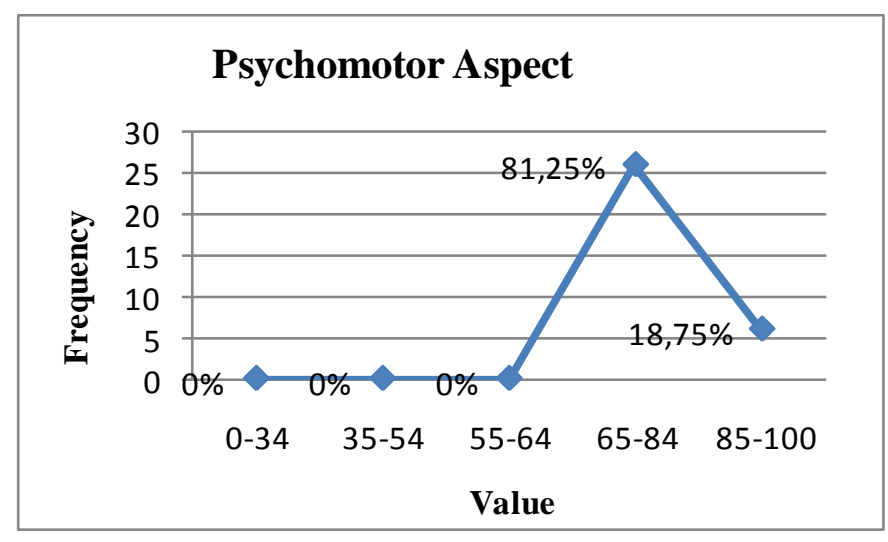

Fig. 1. Results of Student Activities On Psychomotor

In the curve shown that psychomotor abilities of students were very good because the facilities made students to learn and to build their structure of thinking.

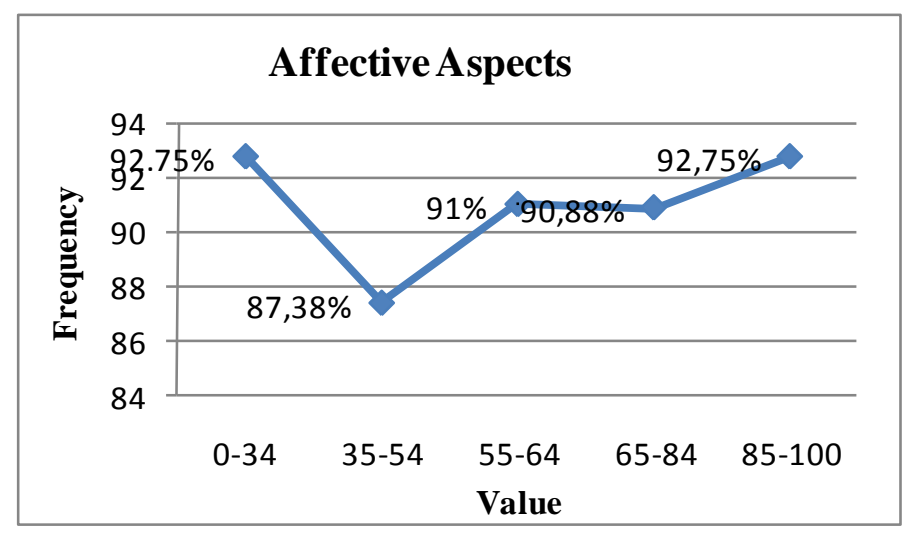

Fig. 2. Results of Student Activities for Affective Aspects

2) The students' response to the practicality of student worksheet

The results of student responses included the categories of good and very good.

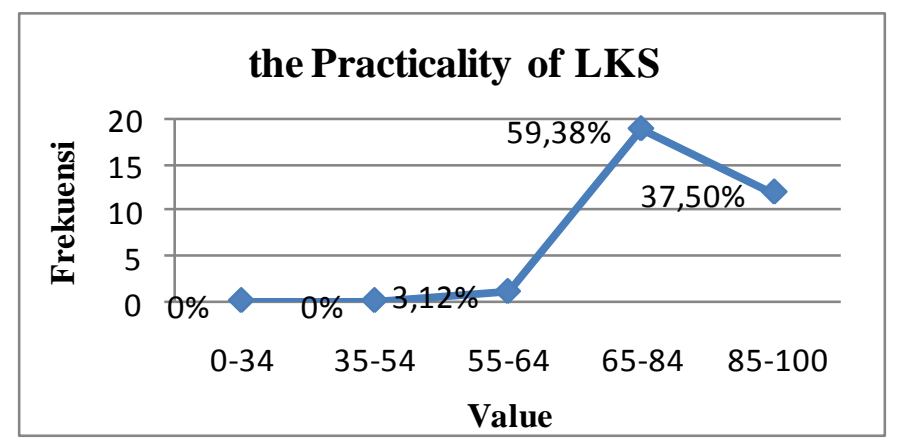

Fig. 3. Response Student Practicality toward student worksheet 
3) Implementation worksheet based guided inquiry

The test results have done, and legibility student worksheet-based guided inquiry against student worksheet practicality of these three aspects are all categorized as very good in readability of 3.32 or excellent category. This is reinforced by student learning outcomes in the three cognitive, psychomotor and affective everything is in good and well category.

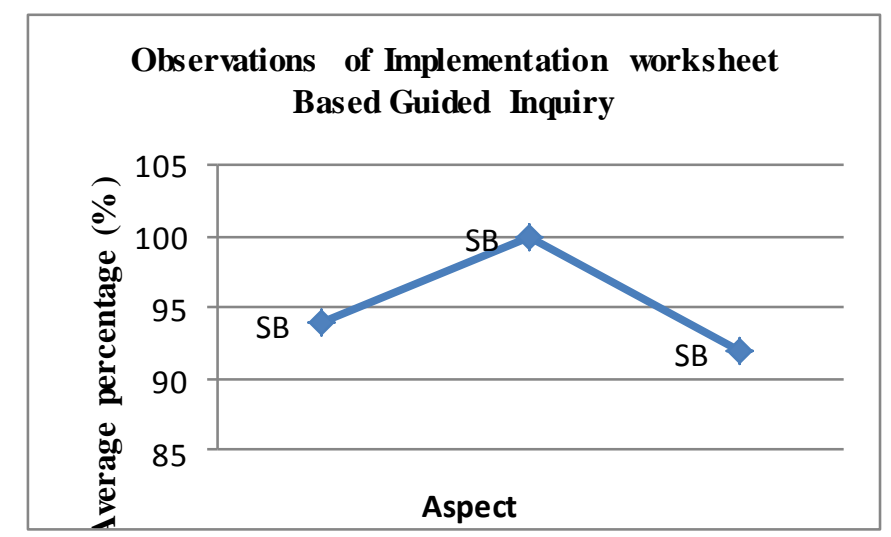

Fig. 4. Observations result of Implementation Learning with student worksheet

Students' response to the implementation test and test readability of the language in the student worksheet improved and clarified to: (1) illustration image in student worksheet further clarified, (2) description illustrations greatly improved, and (3) cover student worksheet is designed not easily torn.

Learning the rate of a chemical reaction either through meetings in the classroom and practical-based inquiry guided can improve critical thinking skills of students, students can better understand the concept of reaction rate through the issues related to the experience and everyday life so that it can be more meaningful [4].

\section{CONCLUSION}

Based on explaining above that the student worksheetbased guided inquiry developed referring to the model of development of the 4-D have valid criteria corresponding assessment results validator, and effective based on the results of student learning in the form of cognitive value in the category completed, and practical, based on implementation test results, readability test, the response of teachers and students' response to student worksheet at high and very high categories.

\section{REFERENCES}

[1] W. F. Pinar, International handbook of curriculum research. Routledge, 2013.

[2] H. F. O’Neil, Learning strategies. Academic Press, 2014.

[3] S. Thiagarajan, 'Instructional Development for Training Teachers of Exceptional Children: A Sourcebook.', 1974.

[4] M. Pedaste et al., 'Phases of inquiry-based learning: Definitions and the inquiry cycle', Educ. Res. Rev., vol. 14, pp. 47-61, 2015. 